\title{
Experiments In Bertrand Competition With Factor Markets
}

\author{
Randall E. Waldron, University of South Dakota, USA \\ Michael A. Allgrunn, University of South Dakota, USA \\ Guoqiang Pei, University of South Dakota, USA
}

\begin{abstract}
We present a classroom experiment which introduces product differentiation and factor markets into the traditional Bertrand framework. We find that student behavior converges toward the market outcomes predicted by theory. We also find that the experiment enhances student understanding of Bertrand price competition in a market with product differentiation and factor markets, and also appears to increase student satisfaction.
\end{abstract}

Keywords: economic experiments; Bertrand competition; economic pedagogy.

\section{INTRODUCTION}

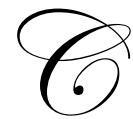

ompetition in oligopolistic markets is typically modeled using either quantity or price as the strategic choice variable, dating back to Cournot (1838) and Bertrand (1883), respectively. As game theory and behavioral studies have become more prominent in economics, both Cournot and Bertrand competition have been couched in the modern dressings of strategic interaction, and are often introduced in courses dealing with these topics as well as industrial organization courses and others covering market structures. In this paper we present the results of an experiment in Bertrand price competition with differentiated products and factor markets. The experiment was conducted in a course on managerial economics for undergraduate business students as a pedagogical tool for teaching about oligopoly, so we also report the results of pre-experiment and post-experiment tests to gauge the effectiveness of the experiment for instructional purposes.

In this classroom experiment, we expose students to both strategic interaction in the output market and scarcity in input markets. We assume demand functions for the final product that essentially replicate Bertrand price competition with differentiated products, which we motivate by telling the "firms" (groups of students) that they sell similar products in different geographic areas to consumers who are distributed in such a way as to make their purchase decisions on the basis of both price and distance from the firm. We further assume a simple Leontief fixed-proportions production function, so that firms must acquire both labor and capital to produce their output. Factor endowments are perfectly inelastically supplied for each round, but vary in scarcity over the course of repeated rounds of the game. In each round of the game, firms simultaneously submit bids for labor and capital and set their output price, and then are shown the outcome of their decisions. Prices, production, and profits are then tracked throughout the game to illustrate trends, changes due to shocks (factor endowment changes), and possible convergence to equilibria in both output and factor markets.

Experiments with simple Bertrand price competition with identical products have been conducted both as a test of the Bertrand model and as a pedagogical tool. The traditional Bertrand model with identical products predicts that price will be driven to the marginal cost of production. Dufwenberg and Gneezy (2000) find that prices in the Bertrand game remain above marginal cost when there are only 2 competitors, but that prices do drop when there are 3 or 4 competitors. Ortmann (2003) describes a classroom demonstration used to teach Bertrand price undercutting in an upper-level economics course, and finds that larger potential payoffs to participants tend to increase the rate at which undercutting occurs. There are also a number of studies suggesting that experiments are an effective pedagogical tool (Beil and Delemeester, 1999; Gremmen and Potters, 1997), and others that find student satisfaction is higher when instructors use experiments instead of the standard "chalk-and-talk" approach (Mullin and Sohan, 1999; Yandell, 1999). 
Our contribution to the literature is to introduce product differentiation and factor markets into the Bertrand framework in an experimental setting. Bertrand competition with product differentiation typically leads to pricing above marginal cost, which in some respects provides a more interesting experiment, because the expected outcome is less intuitively obvious. Incorporating factor markets facilitates competition in multiple distinct but related markets simultaneously, again creating a more interesting experimental environment. This experiment is somewhat more complex than others in the literature, but it allows us to both test and teach more concepts in the same classroom exercise. Since compiling bid data and calculating payoffs can be time-consuming even in a simple classroom experiment, we also designed a computer interface to facilitate the additional complexity. We find that participants did move toward the predicted equilibria, that student understanding of both strategic interaction and factor markets increased, and that student satisfaction was higher than in previous courses that did not incorporate the experiment.

\section{BERTRAND MODEL WITH FACTOR MARKETS}

Oligopolistic price competition with differentiated products leaves firms facing demand functions that are decreasing with respect to own price and increasing in rivals' prices. For the three-firm case, we assume specific and symmetric linear demand functions:

$Q_{\alpha}^{D}=100-3 p_{\alpha}+p_{\beta}+p_{\gamma}$
$Q_{\beta}^{D}=100-3 p_{\beta}+p_{\alpha}+p_{\gamma}$
$Q_{\gamma}^{D}=100-3 p_{\gamma}+p_{\alpha}+p_{\beta}$

for the firms $\alpha, \beta$, and $\gamma$. Each firm faces a production function showing output produced by capital and labor in fixed proportions:

$Q_{i}=\min \left\{K_{i}, L_{i}\right\}$

for $\mathrm{i}=\alpha, \beta$, and $\gamma$. Factors of production are supplied perfectly inelastically in their respective markets, and firms bid for these resources competitively.

Factor scarcity drives the equilibrium results. If factor usage is unconstrained and freely available, such that production costs are zero, then the Nash-Bertrand equilibrium has each firm producing 75 units, pricing output at 25 , and utilizing 75 units each of capital and labor, with each factor priced at zero. Firm profits are 1,875 each.

In the event that labor or capital is too scarce to allow this outcome, the least abundant of the factors determines the new equilibrium. Assuming endowments, for example, of $\mathrm{K}>\mathrm{L}$ and $\mathrm{L}<225$, then the symmetrical outcome in which labor determines output levels would have $L_{i}=L / 3$ and therefore $Q_{i}=L / 3$ for $i=\alpha, \beta$, and $\gamma$. The equilibrium output price corresponding to this level of output would be $\mathrm{p}_{\mathrm{i}}=100-\mathrm{L}_{\mathrm{i}}$. Since labor is a homogeneous input, competition among Bertrand oligopsonists will push the equilibrium wage for labor up to consume all possible profits, so that the wage rate $\mathrm{w}=\mathrm{p}=100-\mathrm{L} / 3$.

In contrast to equilibrium play, cooperation among the firms in the presence of a sufficient endowment of resources ( $L, K \geq 150$ in this case) would entail pricing at $\mathrm{p}_{\mathrm{i}}=50$ and producing at $\mathrm{q}_{\mathrm{i}}=50$ for $\mathrm{i}=\alpha$, $\beta$, and $\gamma$, with resulting profits of 2,500 per firm, noting that the firms would conspire to keep input costs at zero. ${ }^{2}$ In the event that $\mathrm{L}<150$ or $\mathrm{K}<150$, the cooperating firms would distribute the scarce input (say, labor) equally, with $\mathrm{Q}_{\mathrm{i}}=\mathrm{L}_{\mathrm{i}}=\mathrm{L} / 3$ and $\mathrm{p}_{\mathrm{i}}=100-\mathrm{L}_{\mathrm{i}}$.

\section{EXPERIMENT DESIGN}

This classroom experiment was implemented in a senior-level course entitled Economics for Managers; the seventeen participating students were business majors, and most had taken only principles level courses in 
economics previously. Students were randomly assigned to the competing firms, $\alpha, \beta$, and $\gamma$. The experiment, presented as a business competition game, was explained to the student participants, and each team was given a written set of instructions. Each team was also given a form on which to enter their bids for labor and capital and the price chosen for output, and on which to record results. For each round of the game, each firm simultaneously chose its output price and submitted up to four bid levels for both capital and labor. For example, a firm could specify that it was willing to pay 10 for its first 20 laborers, 8 for its next 10,4 for its next 15 , and 2 for 20 more laborers, thus creating a "stair-step" demand schedule. Participants were not initially informed of the specific demand function characteristics for output, nor of the endowments of capital and labor; however, all of this information was visually available on the computer interface that the entire group saw when the results of each round were displayed.

Participants were told that the output demand parameters would not change during the game, but that the endowment of resources would change after the initial 8 rounds of the game. The game would then continue 6 more rounds under the new endowment conditions, totaling 14 rounds in all, completed over several class meetings during a two week period. Firms were prohibited from discussions with one another, although no meaningful monitoring or punishment was feasible had the rule been violated. No collusion was observed at any point.

A computer program written specifically for this game provided a display at the conclusion of each round to reveal the results to participants. Everyone was then able to see each firm's output price as well as each firm's entire demand schedule for capital and labor. Factor markets were treated as competitive markets, in that firm bids were aggregated to form a market demand, and matched with the perfectly inelastic supply of each input to determine an equilibrium price. The demand of all bidders at or above this equilibrium price was then met with all firms paying the equilibrium price, regardless of inframarginal bidding. In some instances, firms demanded more than could be supplied at the margin at the equilibrium price, in which case the factor was allocated first to those firms requesting the most at that price.

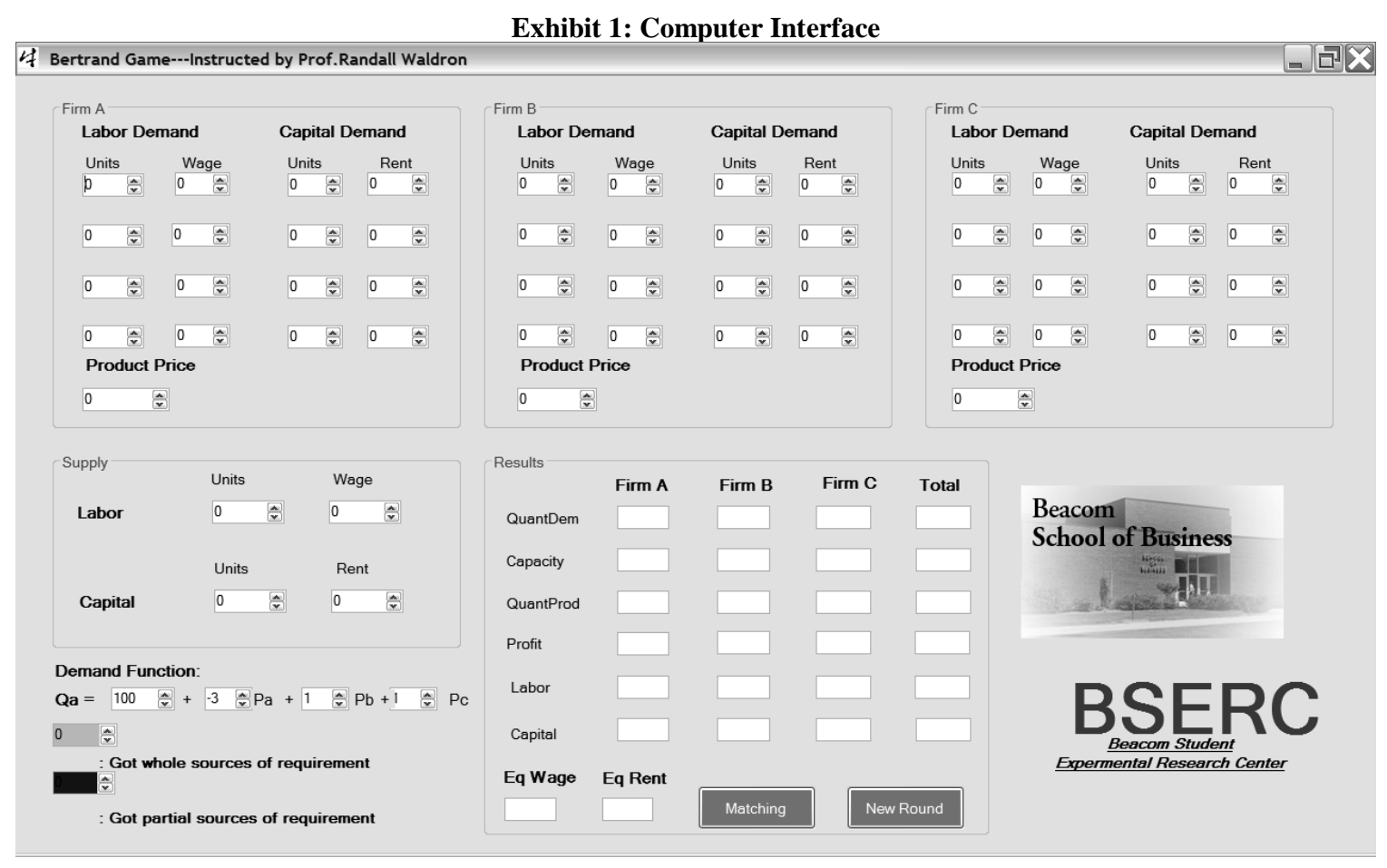

Each firm's output demand was generated by the equations in the model in the previous section, and each firm's capacity was determined by the quantities of capital and labor it successfully purchased in the factor markets. The quantity of output sold by each firm was the lesser of its demanded quantity and its capacity. Each firm paid for 
all its capacity, however, including any excess capacity inadvertently purchased. The data displayed by the computer interface appeared as shown in Exhibit 1. Firms were allowed several minutes to discuss their strategy options prior to submitting entries for each round. Students generally appeared to engage in the experiment enthusiastically.

\section{EXPERIMENT RESULTS}

We expected play to converge to the Nash-Bertrand equilibrium once participants had some experience with the game. None of the students are believed to have had substantial training in game theory, and therefore were unlikely to mathematically calculate the equilibrium or a best response function upon being introduced to the game. Furthermore, firms were not initially told the parameters of the game, but instead were instructed to submit their output price and input bids using integers between 0 and 100. Therefore we expected initial convergence to occur over the first few rounds as familiarity with the game's parameters evolved, and then again in response to a change in factor endowments following round 8.

In rounds $1-8, \mathrm{~L}=\mathrm{K}=240$, so we expected to see the respective input prices for labor and capital, the wage and rental rates, move to 0 , with output prices converging to $\mathrm{p}=25$ for all three firms. In rounds $9-14, \mathrm{~K}=$ 240 as before, but $\mathrm{L}=120$. We expected the rental price of capital to remain 0 , but we anticipated that the wage rate for labor would rise to 60 . Output prices would also be 60 under the constrained labor scenario, in which case firm profit would fall from 1,875 per round early in the game to 0 in the last 6 rounds.

The experiment results are displayed in Figures $1-3$. Figure 1 shows output prices chosen by each of the three firms over all 14 rounds. Initially firms priced near 50 - most likely a focal point because they were simply instructed to choose integers between 0 and 100 - but then quickly reduced prices upon observing that higher profits were going to firms pricing lower. Notably, prices do appear to have converged, particularly in rounds $4-8$, but only to the low $30 \mathrm{~s}$, and not the slightly lower price of 25 we predicted. However, prices hovered much closer to the equilibrium price than the cooperative price of 50. With the introduction of labor scarcity in round 9, output prices rose, but only gradually and not to the predicted new equilibrium level of 60 . However, prices on average appear to have still been rising into round 14 , and so possibly with more rounds convergence to 60 may have occurred.

\section{Figure 1: Output Prices}

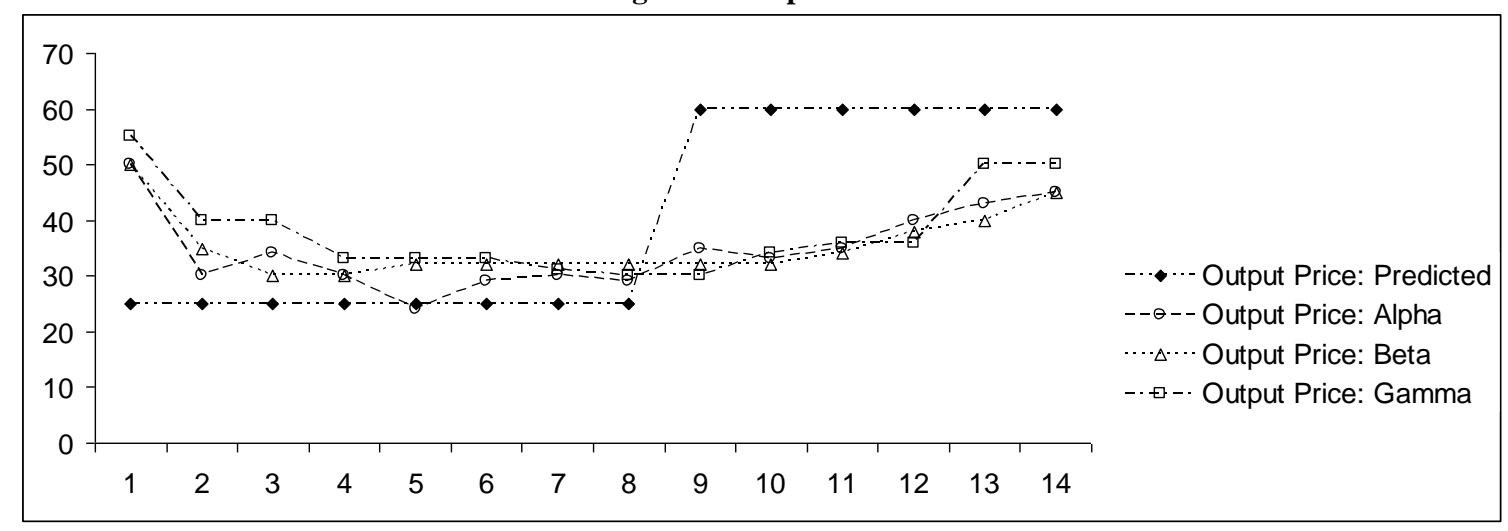

Figure 2 shows the market price outcomes for labor and capital across all 14 rounds of the game. Initially, firms appear to have bid up input prices above predicted levels, acquiring labor and capital that was not needed, given the output demand generated by the chosen output prices shown above. Consequently, in the early rounds, firms frequently found themselves with excess capacity, and profits were significantly lower than expected. By round 6, however, wage and rental rates dropped nearly to the expected level of 0 and remained there through round 8. Note that market wages and rental rates were identical to each other in each of the initial 8 rounds, indicating that participants fully grasped the nature of the Leontief production function, featuring inputs as perfect complements. 
Following round 8, scarce labor became a binding constraint for firms, and the market wage rate rose dramatically at first, and then more slowly. However, the wage rate never reached the level of output prices, and therefore labor never captured the entire potential profit available in the market as firms resisted bidding away all profits in search of available inputs. Other than anomalous bidding by one firm in round 10, the market rental rate of capital fell to 0 and remained there for the duration of the game, as expected.

Figure 2: Factor Prices

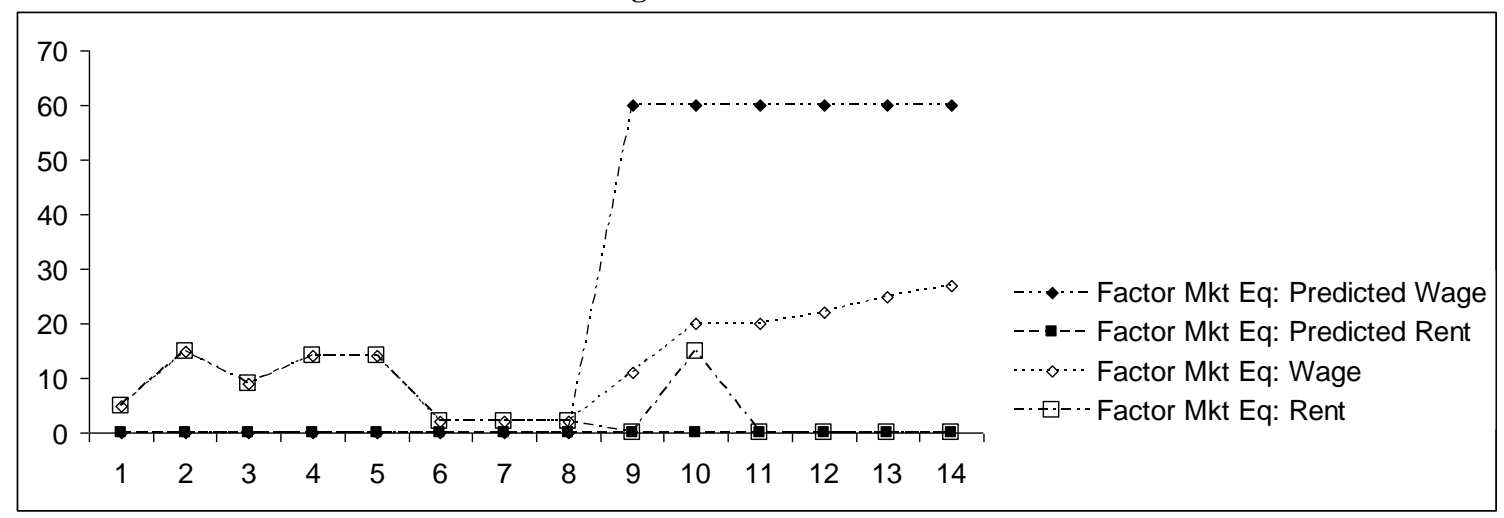

Figure 3 shows the profits for all three firms, which of course directly derive from the output prices and factor prices shown above. During the first 5 rounds profits were erratic, often low, and sometimes negative, as firms experimented with output pricing early on and in particular bid up input prices. Results of rounds $6-8$ appear much closer to those predicted by the Nash-Bertrand model, with profits sustained at very nearly the predicted level of 1875 (output prices were maintained at rates slightly higher than the equilibrium, but this effect was offset by slightly higher than predicted input prices. Profits fell significantly beginning in round 9 and stabilized between rounds $11-14$ at levels somewhat higher than the predicted level of 0 . Output and input prices rose in parallel fashion, enabling profits to remain stable after anomalous bidding in round 10 caused unusual results.

Figure 3: Firm Profits

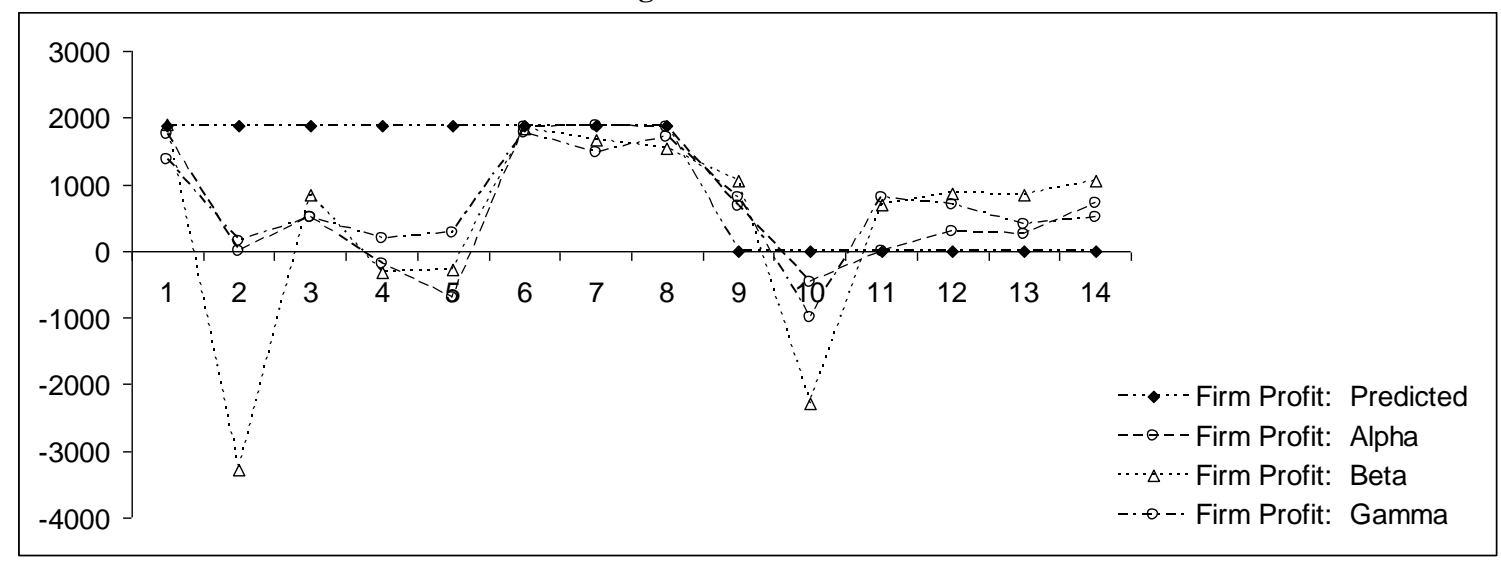

\section{LEARNING ASSESSMENT}

The experiment not only provides a way to test economic theory, but also has pedagogical value. Students experience strategic interaction as oligopolists in the output market and explore the significance of factor markets as well. Richer than a Bertrand simulation by itself, this experiment offers a more realistic opportunity to have 
students think about both competition in the final goods market as well as input procurement. In the process, students can glean a deeper understanding of game theory and come to a point at which they can evaluate hypotheses using the data they have just created in the simulation.

To assess student learning, a brief battery of multiple choice questions was constructed and used for both a pre-experiment questionnaire about anticipated game outcomes as well as post-experiment analysis. Table 1 reports the results. The "Pre-test" and "Post-test" columns show the proportion of students who chose each answer on the respective tests. ${ }^{3}$ The first two questions dealt with the initial scenario in the simulation, in which both factors of production were abundant. Students scored better on both of these questions, as measured by an increased proportion choosing the correct answer. Questions 3 through 5 dealt with the effects of having a limited amount of one input. Students performed substantially better on questions 3 and 4, but did not show much improvement on question 5. Overall, student performance is substantially better on the Post-test, suggesting that students did learn from the experiment. Whether they learned more than they would have from a traditional lecture format is not clear. Consistent with findings in the literature, student satisfaction did appear to be higher than in similar courses without the experiment.

Table 1: Pre-experiment and Post-experiment Learning Assessment

\begin{tabular}{|c|c|c|c|}
\hline Question & Answers (Correct answer in italics) & $\begin{array}{l}\text { Pre- } \\
\text { test }\end{array}$ & $\begin{array}{r}\text { Post- } \\
\text { test }\end{array}$ \\
\hline \multirow{2}{*}{$\begin{array}{l}\text { 1. Suppose there is an abundance of each } \\
\text { input - enough for each firm to be able to } \\
\text { hire all it wants without exhausting the input } \\
\text { capacity. Which of the following best } \\
\text { describes the likely outcome in the market } \\
\text { for inputs? }\end{array}$} & $\begin{array}{l}\text { Firms will bid up the prices of all inputs despite their } \\
\text { abundance, because the firms are competitive with one } \\
\text { another. }\end{array}$ & $2 / 12$ & 2/ 17 \\
\hline & $\begin{array}{l}\text { Market prices for inputs will be very low due to their } \\
\text { abundance, in spite of firms' competition with one another. }\end{array}$ & $\begin{array}{l}10 / \\
12\end{array}$ & $\begin{array}{l}15 / \\
17\end{array}$ \\
\hline \multirow{3}{*}{$\begin{array}{l}\text { 2. Again supposing that there is an } \\
\text { abundance of each input, what will most } \\
\text { likely happen to firms' prices and profits? }\end{array}$} & $\begin{array}{l}\text { Firms will bid away prospective profits on inputs, so that } \\
\text { most revenue will ultimately be paid out to inputs. }\end{array}$ & $2 / 12$ & $1 / 16$ \\
\hline & $\begin{array}{l}\text { Firms will compete away all or most prospective profits as } \\
\text { they compete with one another, but inputs will not be paid } \\
\text { much or any payment. }\end{array}$ & $5 / 12$ & $4 / 16$ \\
\hline & Firms will earn and retain substantial profits. & $5 / 12$ & $\begin{array}{l}11 / \\
16\end{array}$ \\
\hline \multirow{3}{*}{$\begin{array}{l}\text { 3. If the availability of one or more of the } \\
\text { inputs is significantly limited, what will } \\
\text { happen to the price of the inputs, relative to } \\
\text { what you predicted above? }\end{array}$} & $\begin{array}{l}\text { The price of the limited input will go up and the price of the } \\
\text { other will fall or remain the same. }\end{array}$ & $5 / 12$ & $\begin{array}{l}16 / \\
17 \\
\end{array}$ \\
\hline & $\begin{array}{l}\text { The price of all inputs will go up, since inputs must be used } \\
\text { in pairs. }\end{array}$ & $5 / 12$ & $1 / 17$ \\
\hline & The price of inputs will not be affected. & $2 / 12$ & $0 / 17$ \\
\hline \multirow{3}{*}{$\begin{array}{l}\text { 4. If the availability of one or more of the } \\
\text { inputs is significantly limited, what will } \\
\text { happen to the price of the output charged by } \\
\text { the firms? }\end{array}$} & $\begin{array}{l}\text { Firms will raise their output price and be able to retain most } \\
\text { or all of their profitability (i.e., be about as profitable as they } \\
\text { were before). }\end{array}$ & $2 / 12$ & $4 / 16$ \\
\hline & $\begin{array}{l}\text { Firms will raise their output price, but will not be able to } \\
\text { maintain the level of profitability they had before, because } \\
\text { more revenue will go to pay for the inputs. }\end{array}$ & $7 / 12$ & $\begin{array}{l}12 / \\
16\end{array}$ \\
\hline & $\begin{array}{l}\text { Firms will not be able to raise their output price because of } \\
\text { competitive pressure. }\end{array}$ & $3 / 12$ & $0 / 16$ \\
\hline \multirow{4}{*}{$\begin{array}{l}\text { 5. If the availability of one or more of the } \\
\text { inputs is significantly limited, what will } \\
\text { happen to the allocation or distribution of } \\
\text { firm revenues? }\end{array}$} & $\begin{array}{l}\text { Firms will have less revenue, and they will keep a smaller } \\
\text { fraction of their revenue because they must pay more for } \\
\text { their inputs. }\end{array}$ & $5 / 12$ & $9 / 16$ \\
\hline & $\begin{array}{l}\text { Firms will have less revenue, but they will be able to keep } \\
\text { as much of their revenue as they would if there were an } \\
\text { abundance of resources. }\end{array}$ & $2 / 12$ & $1 / 16$ \\
\hline & $\begin{array}{l}\text { Firms will have about the same or more revenue, and they } \\
\text { will be able to keep more of their revenue, as payments to } \\
\text { inputs will fall, stay the same, or at least rise by less than } \\
\text { output price. }\end{array}$ & $2 / 12$ & $1 / 16$ \\
\hline & $\begin{array}{l}\text { Firms will have about the same or more revenue, but they } \\
\text { will be able to keep less of their revenue, because they will } \\
\text { have to pay substantially more for their input }(s) \text {. }\end{array}$ & $3 / 12$ & $5 / 16$ \\
\hline
\end{tabular}




\section{CONCLUSIONS}

This classroom experiment introduces product differentiation and factor markets into the traditional Bertrand framework. We find that as participants play multiple rounds, the market tends toward the outcomes predicted by theory. The experiment enhances student understanding of Bertrand price competition in a market with product differentiation and factor markets, and also appears to increase student satisfaction.

\section{AUTHOR INFORMATION}

Randall Waldron received his Ph.D. from Vanderbilt University in 1994 and holds a B.A. with majors in economics and political science from Northwestern University. He has been employed at The University of South Dakota since 1994. His teaching and research interests focus on applied microeconomics, including game theory, experimental and managerial economics. During the 2006 - 2007 academic year, he was a Fulbright Lecturer at Beijing Jiaotong University in China while on sabbatical from USD.

Michael Allgrunn has been an assistant professor of economics at The University of South Dakota since 2006. His specialties are Econometrics and Labor economics, with research interests in economic pedagogy, immigration, and unemployment insurance. He received his Ph.D. from Michigan State University.

Guoqiang Pei is a graduate student in both Business and Computer Science at The University of South Dakota.

\section{NOTES}

1. With zero costs, profit (total revenue) for firm $\alpha$ is $\pi_{\alpha}=\mathrm{p}_{\alpha}\left(100-3 \mathrm{p}_{\alpha}+\mathrm{p}_{\beta}+\mathrm{p}_{\gamma}\right.$ ), and similarly for firms $\beta$ and $\gamma$. From the first order condition, we find that $\alpha$ 's best response function is $\mathrm{p}_{\alpha}=100 / 6+\mathrm{p}_{\beta} / 6+\mathrm{p}_{\gamma} / 6$, and similarly for firms $\beta$ and $\gamma$. Solving simultaneously for best response and hence Nash-Bertrand equilibrium pricing yields $\mathrm{p}_{\alpha}=\mathrm{p}_{\beta}=\mathrm{p}_{\gamma}=25$. Firms would choose to employ $\mathrm{L}_{\mathrm{i}}=\mathrm{K}_{\mathrm{i}}=75$ to generate the corresponding equilibrium output.

2. The joint profit maximization problem is $\pi=\pi_{\alpha}+\pi_{\beta}+\pi_{\gamma}$. We find that with respect to $\alpha$ the first order condition yields $\mathrm{p}_{\alpha}=100 / 6+\mathrm{p}_{\beta} / 3+\mathrm{p}_{\gamma} / 3$, and similarly with respect to $\mathrm{p}_{\beta}$ and $\mathrm{p}_{\gamma}$. Solving simultaneously yields $\mathrm{p}_{\alpha}=\mathrm{p}_{\beta}=\mathrm{p}_{\gamma}=50$. Firms would choose to employ $\mathrm{L}_{\mathrm{i}}=\mathrm{K}_{\mathrm{i}}=50$ to generate the corresponding joint profit maximizing output.

3. 12 students took the Pre-test. 17 students took the Post-test, with 1 student leaving some questions blank.

\section{REFERENCES}

1. Beil, R., \& Delemeester, G. (1999). Proceedings from Economics and the Classroom Conference '99: The Double Oral Auction: Is it and Effective Teaching Tool? 12-32. Pocatello, ID: Idaho State University and Prentice-Hall Publishing Co.

2. Bertrand, J. (1883). Théorie Mathématique de la Richesse Sociale. Journal des Savants, 499-508.

3. Cournot, A. (1838). Recherches sur les Principes Mathématiques de la Théorie des Richesses. Paris: L. Hatchette.

4. Dufwenberg, M., \& Gneezy, U. (2000). Price Competition and Market Concentration: An Experimental Study. International Journal of Industrial Organization, 18, 7-22.

5. Gremmen, H., \& Potters, J. (1997). Assessing the Efficacy of Gaming in Economics Education. Journal of Economic Education, 28, 291-303.

6. Mullin, D. \& Sohan, G. (1999). Benefit Assessment of Classroom Experimental Economics. Working Paper, United States Air Force Academy.

7. Ortmann, A. (2003). Bertrand Price Undercutting: A Brief Classroom Demonstration. Journal of Economic Education, 34, 21-26.

8. Yandell, D. (1999). Proceedings from Economics and the Classroom Conference '99: Effects of Integration and Classroom Experiments on Student Learning and Satisfaction. 4-11. Pocatello, ID: Idaho State University and Prentice-Hall Publishing Co. 


\section{NOTES}

